\title{
The Influence of Leadership Style on Accountants' Commitment with Enterprise: An Empirical Study on Vietnamese FDI Firms
}

\author{
Duc Tai DO*, Tien Hung NGUYEN**, Thi Hong Nga NGUYEN ${ }^{* * *}$, Hong Hanh HA ${ }^{* * * *}$, Thi Tam LE ${ }^{* * * * *}$ \\ Received: January 16, 2020 Revised: January 30, 2020 Accepted: February 6, 2020.
}

\begin{abstract}
The research aims to examine the impact of leadership style on accountants' commitment with FDI firms in Vietnam based on theory of Bass and Avolio (2004). A survey with 110 accountants in FDI firms was conducted. The total of 110 respondents with full information were used for data entry and analysis. Through quantity methodology, we used Cronbach's Alpha, EFA and correlation analysis to determine the relationship between leadership style and three dependent variables including affective, normative and continuance commitment. The results showed that the leadership style had positive relationships with accountants' commitments. In particular, normative commitment with FDI firms of accountants is the most strongest. In addition, there is no statistically difference in the level of three commitments with FDI firms of accountants for three groups of job description. From the findings, this study suggests several recommendations to improve accountants' commitments such as intellectually stimulating, individualized consideration, inspirational motivation, idealized influence, and idealized influence behavior. The results are considered as a useful reference for establishing policies to attract talent personnel toward to sustainable development of firms. Commitment with the organization is a crucial factor to gain a competitive advantage and guide the success of organizations by satisfying customers, maintaining productivity and efficiency.
\end{abstract}

Keywords : Leadership Style, Commitment, Accountants, FDI firm, Vietnam

JEL Classification Code: G21, J53, M54

\section{Introduction}

Commitment with the organization is having a firm belief in the organization's goals and values (Meyer \& Allen, 1991). Commitment with the organization is the relative strength of employee identity with the organization

${ }^{*}$ First Author, Lecturer, Faculty of Accounting, University of Labor and Social Affairs, Vietnam. Email: taiketoanquocte@gmail.com **Lecturer, Faculty of Economics, Hanoi Open University, Vietnam. Email: tienhung.kt@hou.edu.vn

${ }^{* * \star}$ Associate Professor, Faculty of Accounting and Auditing, Hanoi University of Industry, Vietnam. Email: hongnga2311@gmail.com and nguyenthihongnga@haui.edu.vn

****Lecturer, School of Accounting and Auditing, National Economics University, Vietnam. Email: hahonghanh1@gmail.com

${ }^{* * * * * C o r r e s p o n d i n g ~ A u t h o r . ~ L e c t u r e r, ~ D e p a r t m e n t ~ o f ~ A c c o u n t i n g, ~}$ Thuyloi University, Vietnam [Postal Address: No. 175, Tay Son Road, Dong Da District, Hanoi, 100000, Vietnam]

Tel. +84984537282, Email: lethitam@tlu.edu.vn

(c) Copyright: The Author(s)

This is an Open Access article distributed under the terms of the Creative Commons Attribution NonCommercial License (https://creativecommons.org/licenses/by-nc/4.0/) which permits unrestricted noncommercial use, distribution, and reproduction in any medium, provided the original work is properly cited. and the active participation of employees in a given organization (Mowday, Steers, \& Porter, 1979). An individual's commitment is an important factor to gain a competitive advantage (Bryant, Altman, \& Spudich, 2007). The commitment of employees with the organization has guided the success of organizations and it is also the employees who are loyal to, proud of and love the organization to help the organization achieve its big business goals by satisfying customers, maintaining productivity and efficiency to achieve financial goals (Do \& Le, 2015).

Leadership is the way a person plays his or her role, the way they act, the way they make decisions, the way they interact with people and the way they treat people. In the process of different leadership, the work results largely depend on the leadership method. Good leadership style contributes to rational and effective implementation of the set goals and tasks (Bui, 2017). The theory of Meyer and Allen (1991) and Bass and Avolio (2004) are used in many studies of organizational commitment and the results show that leadership style has a positive influence on employee 
commitment with the organization. In this study, the authors have applied the model of Bass and Avolio (2004) to analyze and measure the impact of the factor "leadership style" on the commitment with FDI firms of accountants in Vietnam. The research results are a useful reference for FDI firms, can be used as a basis for developing policies to attract personnel and retain talents for the development of firms.

\section{Literature Review}

A good leader will develop a right strategy and structure to support employees, make policies and offer rewards as recognizing employee commitment and contribution, to minimize employee leaving the organization. (Fiedler, 1967; Sheard \& Kakabadse, 2004). Leaders will give vision and empower and motivate employees (Joplin \& Daus, 1997; Ogbonna \& Harris, 2011).

Koopman (1991) studied how leadership styles affect employees and the author thinks that employees who like boss's leadership style will love their organization even more. Eisenberger and Cameron (1996) also suggested that employees feel that if they are cared for by their leaders, they will have a higher commitment. Moreover, when employees understand their responsibilities, they will be more connected with the organization and in particular they will become more creative at work. Tuna, Ghazzawi, Tuna, and Çatir (2011) studied the inspirational leadership style influencing the organizational commitment of tourism and hotel staff in Turkey. Research shows that inspirational leadership styles improve employee commitment and loyalty to the organization. On the other hand, the study also shows an intimate relationship between inspirational leadership style and normative commitment (NC). The leadership style inspires employees with the vision, values and organizational priorities, inspires trust and confidence in the organization.

Senthamil and Palanichamy (2014) indicated leadership styles and their influence on organizational commitment. The two authors have tried to discover the most prefer leadership behavior among the leadership styles; inspiring leadership and its influences on employee commitment in BHEL, Pakistan. The two authors studied the sample with 158 respondents who were senior engineers and training engineers. The authors used One-Way ANOVA statistical tools, correlation analysis and regression to find significant differences in the leadership styles of leaders in different positions and salary for those positions. At the same time, it is also important to find out the relationship between popular leadership styles and organizational commitment. The results showed that direct leaders have a positive and significant influence on Affective commitment (AC);
Normative Commitment (NC) and more importantly, have a positive effect on Continuance commitment (CC). The results also indicated that leaders in different leadership positions have different leadership styles and have a positive impact on organizational commitment.

Tran and Nguyen (2017) surveyed 337 employees of South Asia Commercial Joint Stock Bank in Ho Chi Minh City, using quantitative methods. The result illustrated that leadership styles including transformational leadership style and transactional leadership style have a positive impact on the employees' affective commitment to the bank. Bui (2017) analyzed the influence of leadership style on employee commitment in joint stock commercial banks in Ho Chi Minh City. Research results show that Affective commitment is influenced by all three styles, the strongest of which is leadership style that encourages innovation, followed by considerate leadership style, more tending to mission-oriented leadership style. Normative Commitment is only influenced by a caring leadership style and a leadership style that encourages innovation. Continuance commitment is influenced by leadership style that encourages innovation.

There are many researches about leadership style affecting commitment of employees in different fields such as bank employees in Ho Chi Minh City (Bui, 2017; Tran \& Nguyen, 2017), senior engineers and training engineers in BHEL, Pakistan (Senthamil \& Palanichamy, 2014); tourism and hotel staff in Turkey (Tuna, Ghazzawi, Tuna, $\&$ Çatir, 2011). However, no research has been conducted so far to analyze and measure the impact of leadership style influencing on accountants' commitment with FDI firms. By inheriting those previous studies, this research by selecting appropriate research methods continues to expand and develop a new model to analyze, evaluate and measure the influence of leadership style on accountants' commitment with FDI firms in Vietnam.

\section{Theoretical Background}

\subsection{Theory of Commitment to Organization}

The three-element theory of organizational commitment by Meyer and Allen (1991) is thought to be the leading theory on this topic. The authors argue that the three components of commitment to the organization include (i) affective commitment; (ii) normative commitment and (iii) continuance commitment. Meyer and Allen (1993) suggest that affective commitment is seen as emotional engagement, close and engaging engagement of employees with that organization and for that purpose. Meyer and Allen (1997) continue to argue that retention staff is a member of the organization because of their commitment to the 
organization rather than any other options.

Normative commitment is a commitment of someone who believes that they must stay with the organization or that they feel compelled to stay with the organization. Meyer and Allen (1991) support this type of commitment and define it as a "sense of obligation to stay."

Continuance commitment implies employees' awareness of the costs of leaving an organization (Meyer \& Allen, 1991). Organ and Ryan (1995) found that continuance commitment does not have a significant relationship with the organization's citizenship while other studies suggest that it has a negative relationship. Meyer and Allen (1997) further explain that employees who share and demonstrate a long-term commitment to an organization often find it difficult to leave. Apply the theory to research: Research of Do, Chu, Ha, and Vu (2019) relies on the theory of organizational commitment to identify attributes of (indicators) dependent variables: The commitment with FDI firms of accountants. This study inherits the results of Do, Chu, Ha, and $\mathrm{Vu}$ (2019).

\subsection{Theory of Leadership Style}

There are many notions about leadership style. The first approach is the behavioral (Lewin, 1939) dividing leadership styles into three categories: authoritarian leadership styles, democratic leadership styles and liberal leadership styles. Another approach is a leadership manner (Afanaxep, 1980). Researchers think that leadership manner is a working style of a leader. Manner is a specific expression of style. But they are different: The manner is more personal, the style is more social. Chalvin (1993) suggests the commitment-based and cooperative approach. $\mathrm{He}$ argues that leadership style is the result of the relationship between personality and environment. Personality is the psychological characteristics of workers (personality, temperament, intellect, trends, qualifications) The environment includes the current state of the organization's physiological characteristics of superiors and colleagues, habits, traditions, psychological atmosphere, organizational human resources, socio-economic conditions of the country, moral values system, ideology, etc.

Bass (1990) develops two applied approaches including transformational leadership style and transactional leadership style. For transformational leadership style, Bass (1990) confirms that leaders required employees' ideas and ethical values to be higher, encouraging employees to make more efforts for organization. Transformational leadership style from the leader helps their employees work proactively and have intrinsic motivation which then positively affect job performance (Lee, 2018; Nguyen, Mai, \& Huynh, 2019). According to Bass and Avolio (2004), a transformational leadership style consists of 5 attributes (indicators): (i) Intellectual Stimulation (IS), (ii) individualized consideration (IC), (iii) Inspirational Motivation (IM); (iv) Idealized Influence - attribute (IA) and (v) Idealized Influence Behavior (IB). While for the transactional leadership style, Bass (1990), Suong, Thanh, and Dao (2019) argue that transactional leadership is actually an exchange relationship between leaders and subordinates. The relationship is merely a mutually beneficial relationship for both parties. Bass and Avolio (1997) describe transformational leadership including components: Contingent Reward (CR), Management by Exception - Active - MBA.

By analyzing the above leadership style approaches, the authors argue that leadership style presents not only direction, talent, originality but also leadership influence on employees. The leadership style is individualistic, historical, ideological, ethical, psychosocial, and community tradition. No style of leadership is perfect, or completely bad; no specific leadership style that will bring success to every case. This research inherits the attributes of transformational leadership style of Bass and Avolio (2004) to analyze and measure the influence of leadership style on the commitment with FDI firms of accountants.

\section{Research Methodology}

Inheriting the results of previous studies by Bass and Avolio (2004) and by using a qualitative research approach namely interviews with selected experts to perform a quantitative research, we have identified leadership style (LS) to determine the commitment with FDI firms of accountants. Then, we made a questionnaire consisting of 5 observation variables in a 5-point Likert scale. Independent variables are measured from 1 "without effect" to 5 "strongly" (see Table 1). The collection of data was accomplished through a survey of 150 accountants, for the period 2018-2019, close to this study period. Therefore, their feedback on the commitment with FDI firms of accountants is considered very appropriate.

Out of 150 questionnaires we sent, we received the feedback of 130 respondents. After checking the information on the returned questionnaires, we had only 110 questionnaires with full information for data entry and analysis, the size of this sample was consistent with study of Hair, Anderson, Tatham, and Black (1998). Therefore, the rest of observations for model 1 are 110 surveys (73.3\%). Most respondents have bachelor degree or higher. As can be seen, all participants are at high quality knowledge, and this makes the survey reliable. We used the exploratory factor and correlation analysis to determine the impact of leadership style on the commitment with FDI firms of accountants. 
Dependent variable: The commitment with FDI firms of accountants includes 12 attributes (indicators). Of which, Affective commitment (AC) consists of 4 attributes, Normative Commitment (NC) includes 4 attributes and Continuance commitment (CC) comprises 4 attributes (Do, Chu, Ha, \&Vu, 2019).

Independent variable: The independent variables are described in Table 1.

Job description is used to comparison for the results of the commitment with FDI firms of accountants between the three subjects, including accounting staff, general accounting and chief accountant.

Table 1: Determinants and Its Coding

\begin{tabular}{|c|c|c|}
\hline Code & Scale & Source \\
\hline LS1 & Leadership style (LS) \\
\hline LS2 & $\begin{array}{c}\text { Individualized } \\
\text { consideration }\end{array}$ & $\begin{array}{c}\text { Bass \& Avolio (2004), results of } \\
\text { expert interviews }\end{array}$ \\
\hline LS3 & $\begin{array}{c}\text { Inspirational } \\
\text { motivation }\end{array}$ & $\begin{array}{c}\text { Bass \& Avolio (2004), results of } \\
\text { expert interviews }\end{array}$ \\
\hline LS4 & $\begin{array}{c}\text { Idealized influence - } \\
\text { attribute }\end{array}$ & $\begin{array}{c}\text { Bass \& Avolio (2004), results of } \\
\text { expert interviews }\end{array}$ \\
\hline LS5 & $\begin{array}{c}\text { Idealized influence } \\
\text { behavior }\end{array}$ & $\begin{array}{c}\text { Bass \& Avolio (2004), results of } \\
\text { expert interviews }\end{array}$ \\
\hline
\end{tabular}

From the above analysis, we have designed a research model as shown in Figure 1.

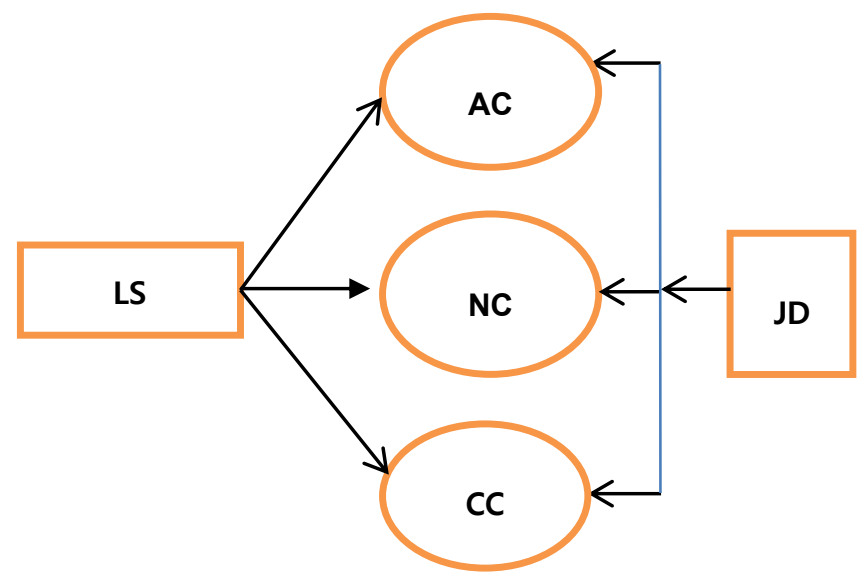

Figure 1: Research model

\section{Research Results}

\subsection{General Information of Respondents}

Table 2 shows that among the 110 respondents, $29.1 \%$ of the participants were male while the remaining $78 \%$ were female, representing for $70.9 \%$. 50 people aged 22 to 27 , accounting for $45.5 \%$; and $54.5 \%$ of the participants were over 27 years old. Among the 110 respondents, accounting staff, general accounting were represented for $35.5 \%$ and $33.6 \%$, respectively while the remaining $34(30.9 \%)$ were chief accountant. Of these, $35.5 \%$ of the participants have from 1 to 5 years and the remaining $64.5 \%$ had more than 5 years of job experience. Moreover, the respondents agreed with the independent variable of "Leadership style" where five attributes were quite high with an average of 3.562 compared with the highest of the Likert 5-point scale. All 5 attributes were rated at average of 3.345 or higher.

Table 2: General information of respondents

\begin{tabular}{|c|c|c|c|}
\hline & Frequency & Percent & $\begin{array}{c}\text { Cumulative } \\
\text { Percent }\end{array}$ \\
\hline \multicolumn{4}{|c|}{ Gender } \\
\hline Male & 32 & 29.1 & 29.1 \\
\hline Female & 78 & 70.9 & 100.0 \\
\hline \multicolumn{4}{|c|}{ Age } \\
\hline Over 27 years old & 60 & 54.5 & 54.5 \\
\hline From 22 to 27 years old & 50 & 45.5 & 100.0 \\
\hline \multicolumn{4}{|c|}{ Job description } \\
\hline General accountants & 37 & 33.6 & 33.6 \\
\hline Chief accountants & 34 & 30.9 & 64.5 \\
\hline Accounting staff & 39 & 35.5 & 100.0 \\
\hline \multicolumn{4}{|c|}{ Seniority work } \\
\hline Over 5 years & 71 & 64.5 & 64.5 \\
\hline From 1 to 5 years & 39 & 35.5 & 100.0 \\
\hline Total & 110 & 100.0 & \\
\hline
\end{tabular}

\subsection{Cronbach's Alpha}

To test reliability, variables are measured by the Cronbach's Alpha presented in Table 3. Cronbach's Alpha coefficients of LS, AC, NC and CC are $0.866 ; 0.805 ; 0,772$; 0,810 which have high values. The results also show that all attributes have a Cronbach's Alpha coefficient greater than 0.6 ; the correlation coefficient of all attributes was greater than 0.3 , so all the attributes were statistically significant (Hair, Black, Babin, \& Anderson, 2009). The results also showed that all attributes had a Cronbach's Alpha coefficient greater than 0.6; the correlation coefficient of all attributes was greater than 0.3 , so all the attributes were statistically significant. 
Table 3: Results of Reliable Testing

\begin{tabular}{|l|c|c|c|c|}
\hline & $\begin{array}{c}\text { Scale } \\
\text { Mean if } \\
\text { Item } \\
\text { Deleted }\end{array}$ & $\begin{array}{c}\text { Scale } \\
\text { Variance if } \\
\text { Item } \\
\text { Deleted }\end{array}$ & $\begin{array}{c}\text { Corrected } \\
\text { Item-Total } \\
\text { Correlation }\end{array}$ & $\begin{array}{c}\text { Cronbach's } \\
\text { Alpha if Item } \\
\text { Deleted }\end{array}$ \\
\hline \multicolumn{5}{|c|}{ Leadership style (LS): Cronbach's Alpha: .866 } \\
\hline LS1 & 14.16 & 6.450 & .796 & .840 \\
\hline LS2 & 14.35 & 7.146 & .695 & .865 \\
\hline LS3 & 14.24 & 7.026 & .674 & .870 \\
\hline LS4 & 14.03 & 6.834 & .777 & .846 \\
\hline LS5 & 14.46 & 7.315 & .664 & .871 \\
\hline \multicolumn{7}{|c|}{ Affective commitment (AC): Cronbach's Alpha: .805 } \\
\hline AC1 & 11.21 & 3.947 & .554 & .787 \\
\hline AC2 & 10.85 & 3.557 & .638 & .747 \\
\hline AC3 & 11.08 & 3.489 & .656 & .738 \\
\hline AC4 & 11.06 & 3.987 & .646 & .748 \\
\hline \multicolumn{7}{|c|}{ Normative commitment (NC): Cronbach's Alpha: .772 } \\
\hline NC1 & 12.16 & 3.367 & .608 & .705 \\
\hline NC2 & 12.15 & 2.994 & .651 & .675 \\
\hline NC3 & 12.12 & 3.316 & .487 & .763 \\
\hline NC4 & 12.05 & 3.006 & .567 & .723 \\
\hline Continuance commitment (CC): Cronbach's Alpha: .810 \\
\hline CC1 & 12.03 & 3.219 & .663 & .745 \\
\hline CC2 & 12.06 & 3.326 & .649 & .753 \\
\hline CC3 & 12.04 & 3.320 & .660 & .747 \\
\hline CC4 & 11.98 & 3.431 & .545 & .802 \\
\hline
\end{tabular}

\subsection{Exploratory Factor Analysis (EFA)}

We then conducted Exploratory Factor Analysis (EFA) where the method of extracting coefficients were component and Varimax analyses of the 5 observed independent variables (Table 4). As can be seen in table 4, the results of the EFA show that $0.5<\mathrm{KMO}=0.866<1$. Bartlett's testimony shows sig. $=0.000<0.05$, which means that all variables are interrelated. After implementing the rotation matrix, we got the followings:

One determinant with factor load $>0.5$, Eigenvalues $>1$, and the variance explained $=68.410 \%$. It demonstrates that the factor analysis of the research data is appropriate. Through the quality assurance of the scale and the test of the EFA model, one factor that influence on the commitment with business of accountants of, i.e. Leadership style (LS) was identified.
Table 4: KMO and Bartlett's Test

\begin{tabular}{|c|c|c|}
\hline Kaiser-Meyer-Olkin Measure of Sampling Adequacy. & $\mathbf{. 8 6 6}$ \\
\hline \multirow{3}{*}{$\begin{array}{c}\text { Bartlett's Test of } \\
\text { Sphericity }\end{array}$} & Approx. Chi-Square & 280.946 \\
\cline { 2 - 3 } & Df & 10 \\
\cline { 2 - 3 } & Sig. & 0.000 \\
\hline
\end{tabular}

\subsection{Correlation Analysis}

The results of the correlation matrix are indicated in Table 5. The correlation coefficients of leadership styles with three dependent variables are greater than 0 reflecting a positive relationship. In addition, values of sig. are less than 0.05 which means that all variables are interrelated (Hair, Black, Babin, \& Anderson, 2009).

Table 5: Correlations

\begin{tabular}{|c|c|c|c|c|}
\hline \multicolumn{2}{|c|}{} & AC & NC & CC \\
\hline \multirow{2}{*}{ LS } & Pearson Correlation & .418 & .524 & .324 \\
\cline { 2 - 5 } & Sig. (2-tailed) & .019 & .004 & .011 \\
\hline
\end{tabular}

\subsection{ANOVA Analysis}

ANOVA test help us to perform a comparison for the results of the commitment with FDI firms of accountants between the three subjects, including accounting staff, general accounting and chief accountant. In Table 6, Levene Statistic value of $\mathrm{AC}$ variable is 0.039 (less than 0.05 ). The hypothesis of homogeneity variance among the variable value groups (different job description) has been violated (Hoang \& Chu, 2008). So, we used the Welch test for this case.

Table 6: Test of Homogeneity

\begin{tabular}{|c|c|c|c|c|}
\hline & Levene Statistic & df1 & df2 & Sig. \\
\hline AC & 3.358 & 2 & 107 & .039 \\
\hline NC & 2.470 & 2 & 107 & .089 \\
\hline CC & .041 & 2 & 107 & .960 \\
\hline
\end{tabular}

Table 7 shows that Sig. Welch $=0.575$ is more than 0.05 . There is not statistically significant difference in the level of Affective commitment with FDI firms of accountants for the mentioned three groups of job description. The values of $\mathrm{NC}$ and $\mathrm{CC}$ variables are 0.089 and 0.960 respectively which is greater than 0.05 . The hypothesis of homogeneity variance among the variable value groups (different job description) has not been violated.

Table 7: Robust Tests of Equality

\begin{tabular}{|c|c|c|c|c|}
\hline & Statistic $^{\mathbf{a}}$ & df1 & df2 & Sig. \\
\hline Welch & .558 & 2 & 69.527 & .575 \\
\hline
\end{tabular}


As presented in Table 8, values of Sig. for $\mathrm{CC}$ and $\mathrm{NC}$ are 0.417 and 0.635 respectively which is more than 0.05 . There is not statistically significant difference in the level of Normative and Continuance commitment with FDI firms of accountants for the mentioned three groups of job description.

Table 8: ANOVA

\begin{tabular}{|c|c|c|c|c|c|c|}
\hline \multicolumn{2}{|c|}{ Variable } & $\begin{array}{c}\text { Sum of } \\
\text { Squares }\end{array}$ & Df & $\begin{array}{l}\text { Mean } \\
\text { Square }\end{array}$ & $\mathbf{F}$ & Sig. \\
\hline \multirow{3}{*}{$\mathrm{NC}$} & $\begin{array}{l}\text { Between } \\
\text { Groups }\end{array}$ & .579 & 2 & .289 & .882 & .417 \\
\hline & $\begin{array}{l}\text { Within } \\
\text { Groups }\end{array}$ & 35.112 & 107 & .328 & & \\
\hline & Total & 35.691 & 109 & & & \\
\hline \multirow{3}{*}{$\mathrm{CC}$} & $\begin{array}{l}\text { Between } \\
\text { Groups }\end{array}$ & .320 & 2 & .160 & .456 & .635 \\
\hline & $\begin{array}{l}\text { Within } \\
\text { Groups }\end{array}$ & 37.546 & 107 & .351 & & \\
\hline & Total & 37.866 & 109 & & & \\
\hline
\end{tabular}

\section{Discussion and Conclusion}

\subsection{Characteristics of Accounting Staff in FDI Firms}

In addition to the knowledge and skills in general science and technology, the accounting staffs have the following distinctive features:

- Accountants directly access the ratios, the accounting numbers - the finalization number, not the estimated number. Strategic managers, marketing, producers, engineers, bank credit specialists, etc., mainly approach the estimated number.

- New accountants perform journal entries which are specific and detailed, require meticulously and carefully.

- Accountants often have analytical thinking from an introverted perspective rather than extroverted perspective. Therefore, they are unique in evaluating the leaders of FDI firms.

\subsection{Intellectually Stimulating}

The research results show that the attribute (Indicator) "intellectual stimulation" has a strong influence on the accounting firms' commitment with FDI firms. Therefore, FDI firms need to improve more the following contents: Make accountants feel really comfortable working with leaders, and create trust in accountants from leaders, in order that accountants feel proud when working with leaders. Leaders should always guide accountants to have different views and methods when solving old problems in a more positive way, help accountants to come up with ideas they never had before. Create conditions for accountants to bring into their full capabilities. Encourage initiative from employees (Bui, 2017).

Moreover, when a problem arises, the leader must be very calm, patient to suggest solutions and remove problems at each stitch. Since then, accountants tend to have positive thinking in the profession. They will proactively create and develop their personal abilities. Intellectually stimulating by creating interesting new projects: Instead of just developing a familiar project, leaders try to develop a new project, which can both stimulate the thinking of accountants, and bring many perspectives together.

\subsection{Individualized Consideration}

Paying attention to the work of accountants increases the commitment of accountants with FDI firms. Accountants will feel interested, more connected with their work when they know that the leaders are not only a good leader but also a caring person. Simply, asking the accountants every day will automatically make the leaders become sociable, friendly and leaders can get the respect and respect from everyone. Leaders need to pay more attention to what the accountants expect and try to imagine what accountants are doing. At that time, every accountant will feel the similarity and be proactive in connecting with the business. Experts who joined the interview said that workers who go beyond the work aspect will show excitement. The stories surrounding life will be interesting topics and enthusiastically responded by accountants. Through each talk, the accountant will know that the leaders are interested in listening to them and this is a very simple way of connecting personnel in FDI firms.

One of the necessary qualities of a leader is sincerity. The leader cares about the employee most sincerely. If the leadership only focuses on personal interests and does not pay attention to others, leadership will become dry and forced, without recognition from the staff which will lose the linkage of personnel with FDI firms. The interviewed experts also said that the training and supporting the development of accountants is one of the jobs that show the connection between employees and the interest and investment of FDI firms. In addition to training and consolidating skills for the job, this job also helps accountants have more satisfaction about the policy of training employees. Since then, they have more confidence and encouragement at work, have more job performance and find their attachment to colleagues, to FDI firms. In addition, according to the roadmap to apply international 
financial reporting standards (IFRS) in Vietnam that the Ministry of Finance is implementing, FDI firms are subject to voluntary application first, followed by compulsory application. Therefore, the training for accountants becomes even more urgent.

\subsection{Inspirational Motivation}

Accountants always try to complete their work for the common goal of FDI firms. However, sometimes accountants also cannot avoid being depressed, lacking concentration and enthusiasm at work. At that time, accountants desperately needed their leaders to show their inspiration instead of criticizing them, deducting their salaries or deciding to leave them.

There are many ways to inspire accountants that leaders can apply, such as leaders at the forefront, dare to take responsibility and become an example for accountants to follow working disciplined manner or working together with accountants. At that time, accountants feel that the leaders always accompany, support and understand the difficulties during the working process, and they will try to do their jobs better and commitment with FDI firms. In addition, the management of "equitable public and private" reward and punishment of leaders will make accountants feel that their efforts are properly appreciated and more attached to their work. On the other hand, a reasonable reward and punishment is a positive inspirational to the accountants because they think that their efforts are properly valued so they are more attached to the organization.

\subsection{Idealized Influence - Attribute}

Leaders need to assert their leadership qualities. One of those leadership qualities is clear direction. The talented leaders must have a clear orientation at work, consider the feasibility in accordance with the actual conditions of FDI firms, from which outline long-term strategies, predict possible challenges and find ways to seize the opportunity. On that basis, let accountants see their mission, role and responsibilities in the firm. When accountants understand the opportunities that they will receive in the future in a positive and specific way, they will have more motivation to work hard and effectively to achieve their goals instead of just completing successfully works assigned.

The image and achievements that leaders achieve also create more or less influence on accountants. If the leaders are accomplished with the contribution of many people such as successfully negotiating a new contract, a new project for FDI firms, the success is shared by inviting accountants to attend a meeting. Through the meeting, communicate to the accountants that they absolutely can achieve even greater achievements than that if really effort and dedication. This will help accountants have more enthusiasm and motivation to make more efforts.

Leaders are problem solvers, time managers, emotional managers, and the persons who decentralize responsibilities to employees. The leader must be assertive, showing determination before their decisions; they dare to accept challenges, dangers and risks. Leaders must have confidence. This is the result of a process of experience, skill training, and accumulation of knowledge. A leader with a perseverance quality never surrenders hard, willing to sacrifice personal interests (spending a lot of time on management). In particular, the final quality is the ability to adapt to circumstances (changes management). Image and quality of the leaders in FDI firms have a great impact on the psychology of accountants. Especially, when that image has entered the mind and subconscious of the accountant, it is difficult to fade. This is the invisible attraction of leaders to accountants, which makes them closely associated with FDI firms.

\subsection{Idealized Influence Behavior}

The attraction of leadership is shown by building a strong group of FDI firms, interacting effectively and fulfilling assigned tasks, which is called to build trust between people. Trust is built in the working process, when leaders communicate with subordinates, based on mutual respect. To create commitment, as a manager, leaders should spend time communicating, talking directly to employees, to accountants, be consistent in thinking, acting and always keeping promise. When trust is built and solidified, managers can make a strong impact and attraction to their employees. Attraction of leadership behavior is also shown when leaders treat employees fairly. Fairness is manifested through the evaluation of the employees' capabilities, rewards and salary increases appropriately. In addition, leaders need to listen to feedback from employees (Bui, 2017).

Behavioral leadership reflected in every acts of the leader. Depending on the viewpoints and specific conditions of the enterprise, the leader appropriately applies two concerns: Concern for the people, and concern for the work. People and work should be concerned in a harmonious manner, when the work results are highly satisfactory, people are properly cared for. The leader treats everyone fairly through the evaluation of the performance, capacity assessment, and commendation that will strengthen the engagement of accountants with businesses in general and in the case of FDI firms in Vietnam.

For any organization, the employees, their talent and commitment to the organization play an important role. They are all related to the "soft" approach to human 
resource management, while promoting competitive advantages and stimulating other positive contributions to the organization. Therefore, the following formula can be drawn: "Talent + Commitment with the organization $=$ Labor efficiency and success" of the organization (Tran, 2014). The results also show that 5 attributes (indicators) of transformational leadership style have an influence on the commitment with FDI firms of accountants. In particular, the normative commitment with FDI firms of accountants is most affected.

\section{References}

Afanaxep, V. G. (1980). Labor of the leader. Hanoi, Vietnam: Labor Publishing House.

Bass, B. M., \& Stodgill, R. M. (1990). Handbook of leadership: theory, research, and managerial applications ( $\left.{ }^{\text {rd }} \mathrm{Ed}\right)$. New York, NY: Free Press.

Bass, B. M., \& Avolio, B. I. (1997). Full range leadership development: Manual for the multifactor leadership questionnaire. Palo Alto, CA: Mind Garden, Inc.

Bass, B. M., \& Avoho, B. J. (2004). Multifactor leadership questionnaire: third edition manual and sampler set. Menlo Park, CA: Mind Garden, Inc.

Bryant, Z., Altman, D., \& Spudich, J. A. (2007). The power stroke of myosin VI and the basis of reverse directionality. Proceedings of the National Academy of Sciences of the United States of America, 104(3), 772-777. DOI: 10.1073\%2Fpnas.0610144104

Bui, T. P. L. (2017). The influence of leadership styles on employees' engagement at Ho Chi Minh City-based commercial banks, Economy and Forecast Review, 36, 39-42.

Chalvin, D. (1993). The management style. Hanoi, Vietnam: Science and Technics Publishing House.

Do, X. K., \& Le, K. L. (2015). The study of employee commitment to military petroleum corporation. Journal of Fisheries Science and Technology, 3, 115-121.

Do, D. T., Chu, H. Y., Ha, H. H., \& Vu, B. T. (2019). The commitment with FDI firms of accountants in Noi Bai industrial park - Creative application in economics sociological knowledge. Research Journal of Finance and Accounting, 10(22), 129-135. DOI: 10.7176/RJFA/10-22-15

Eisenberger, R. \& Cameron, J. (1996). Detrimental effects of reward: reality of myth? American Psychologist, 51, 11531166. DOI: 10.1037/0003-066X.51.11.1153

Fiedler, F. E. (1967). A theory of leadership effectiveness. New York, NY: McGraw-Hill.

Hair, J., Anderson, R., Tatham, R., \& Black, W. (1998). Multivariate Data Analysis with Readings (5th Ed.). Upper Saddle River, NJ: Prentice Hall International.

Hair, J. F., Black, W. C., Babin, B. J., \& Anderson, R. E. (2009). Multivariate Data Analysis (7th ed.). Upper Saddle River, NJ: Prentice Hall International.

Hoang, T., \& Chu, N. M. N. (2008). Analysis of research data with SPSS. Hanoi, Vietnam: Hong Duc Publishing House.

Joplin, R. W., \& Daus, C. (1997). Challenges of Leading a Diverse Workforce. Academy of Management Executive, 11(3), 32-47.
Koopman, P. L. (1991). Between Control and Commitment: Management and Change as the Art of Balancing. Leadership \& Organization Development Journal, 12(5), 3-7. DOI: $10.1108 / 01437739110004947$

Lee, J. Y. (2018). The effects of job characteristics on the team creativity of distribution companies: Moderating effects of transformational leadership. Journal of Asian Finance, Economics and Business, 5(4), 161-172. http://doi.org/10.13106/jafeb.2018.vol5.no4.161

Lewin, K., Lippitt, R., \& White, R. K. (1939). Patterns of aggressive behavior in experimentally created social climates. Journal of. Social Psychology, 10, 271-299. DOI: 10.1080/00224545.1939.9713366

Meyer, J. P., \& Allen, N. J. (1991). A three-component conceptualization of organizational commitment. Human Resource Management Review, 1(1), 61-89. DOI:10.1016/1053-4822(91)90011-Z

Meyer, J. P., Allen, N. J., \& Smith, C. A. (1993). Commitment to organization and occupations: Extension of a three-component model. Journal of Applied Psychology, 78(4), 538-551. DOI: 10.1037/0021-9010.78.4.538

Meyer, J. P., \& Allen, N. J. (1997). Advanced topics in organization behavior series. Commitment in the workplace: Theory, research, and application. Newbury Park, CA: Sage Publications, Inc.

Mowday, R., Steers, R. M., \& Porter, L.W. (1979). The measurement of organizational commitment. Journal of Vocational Behavior, 14(2), 224-247. DOI: 10.1016/00018791(79)90072-1

Nguyen, H. M., Mai, L. T., \& Huynh, T. L. (2019). The role of transformational leadership toward work performance through intrinsic motivation: A study in the Pharmaceutical field in Vietnam. Journal of Asian Finance, Economics and Business, 6(4), 201-212. https://doi.org/10.13106/jafeb.2019.vol6.no4.201

Tuna, M., Ghazzawi, I., Tuna, A. A, \& Çatir, O. (2011). Transformational Leadership and Organizational Commitment: The Case of Turkey's Hospitality Industry. Advanced Management Journal, 2, 10-25.

Ogbonna, E., \& Harris, L. C. (2011). Leadership style, organizational culture and performance: empirical evidence from UK companies. International Journal of Human Resource Management, 11(4), 766-788. DOI: 10.1080/09585190050075114

Organ D. W., \& Ryan, K., (1995). A meta-analytic review of attitudinal and dispositional predictors of organizational citizenship behavior. Personnel Psychology, 48, 775-802. DOI: 10.1111/j.1744-6570.1995.tb01781.x

Sheard, A. G., \& Kakabadse, A. P. (2004). A process perspective on leadership and team development. Journal of Management Development, 23(1), 7-106. DOI: $10.1108 / 02621710410511027$.

Senthamil, A. R., \& Palanichamy, P. (2014). Leadership styles and its impact on Organizational Commitment. The Journal of Commerce, 3(4), 15-23.

Suong, H. T. T., Thanh, D. D., \& Dao, T. T. X. (2019). The impact of leadership styles on the engagement of cadres, lecturers and staff at public universities - Evidence from Vietnam. Journal of Asian Finance, Economics and Business, 
6(1), 273-280.

http://doi.org/10.13106/jafeb.2019.vol6.no1.273

Tran, V. T., \& Nguyen, V. D. (2017). Leadership styles and bank employees' affective commitment: The case of Nam a commercial Joint Stock Bank in Ho Chi Minh City. Economy and Forecast Review, 33, 50-52.

Tran, V. N. (2014). The role of commitment between employees and organizations in attracting and appreciating talents. Journal of State Organization, 1, 53-56. 